\title{
Coping with Shocks and Determinants among Indigenous Vegetable Smallholder Farmers in Kenya
}

\author{
Evans Ngenoh ${ }^{1}$, Sindu W. Kebede ${ }^{1 *}$, Hillary K. Bett ${ }^{2}$, Wolfgang Bokelmann' ${ }^{1}$ \\ ${ }^{1}$ Department of Agricultural Economics, Humboldt University of Berlin, Berlin, Germany \\ ${ }^{2}$ Department of Agricultural Economics and Business Management, Egerton University, Nakuru, Kenya \\ Email: *kebedesw@hu-berlin.de
}

How to cite this paper: Ngenoh, E., Kebede, S.W., Bett, H.K. and Bokelmann, W. (2018) Coping with Shocks and Determinants among Indigenous Vegetable Smallholder Farmers in Kenya. Agricultural Sciences, 9, 804-823.

https://doi.org/10.4236/as.2018.97057

Received: April 18, 2018

Accepted: July 21, 2018

Published: July 24, 2018

Copyright ( $) 2018$ by authors and Scientific Research Publishing Inc. This work is licensed under the Creative Commons Attribution International License (CC BY 4.0).

http://creativecommons.org/licenses/by/4.0/

\begin{abstract}
Farm households in developing countries are faced with various challenges one of which is occurrence of unexpected negative events namely shocks. Shocks could be caused by extreme adverse natural events (droughts, storms, flood, and landslides) and market-related events (fuel, food, input and output price fluctuations, volatilities and price hikes). Most of these shocks affect production systems, food markets and local economies, all of which have direct effects on food security. This study explores the prevalence of shocks among indigenous vegetable farmers in Kenya followed by an assessment of the type of coping strategies in response to these shocks. We find that over two thirds of farmers have coping strategies that are not based on market-related insurance mechanisms; rather they use strategies such as working for more hours and selling assets. We analyze which socioeconomic and institutional factors determine households' decision and extent of coping with shocks. The results showed that access to high-value markets and market information were the major factors informing their decision and extent of using coping strategies along with access to critical services such as credit, extension, and farmer groups. This has significant policy implications regarding the dissemination of information and promotion of credit markets through mobile phone-based platforms for easy accessibility in remote rural areas. Social capital should be encouraged because it acts as a necessary and sufficient conduit for information dissemination and mutual support to help farmers' access critical services and resources needed for successful and sustainable implementation of relevant and appropriate coping strategies.
\end{abstract}

\section{Keywords}

Shocks, Coping Strategies, Household Welfare, Smallholders, Kenya 


\section{Introduction}

The global food supply predominantly comes from smallholder farmers in developing countries who represent about 85 percent of the world's farms [1] [2] [3]. However, smallholder farmers face numerous production shocks caused by climate change, extreme adverse natural events (droughts, storms, flood, landslides etc.) and market-related events (such as fuel, food, input and output price fluctuations, volatilities and price hikes [3] [4] [5]. This means that smallholder farmers are vulnerable and less able to escape poverty because shocks have a long-lasting negative impact on their livelihoods and rural development [6] [7] [8]. Most of these shocks affect their production systems, food markets and local economies, all of which have direct effects on food security [9]. Table 1 presents types of shocks and their possible outcomes. The overall impact of shocks is a slowdown in the rate at which smallholder farmers adopt new commercial crops (or technologies), thus exposing their households to food security risks [10]. Shocks may also act as a catalyst for rural-urban migration by forcing many smallholder farmers to abandon farming and search for off-farm work [11] [12]. These constraints are worse in developing countries, where the delivery of public and private sector insurance services are often poorly developed [13].

In Kenya, agriculture is the mainstay of the country's economy: it accounts for 26 percent of GDP, 65 percent of total exports and more than 18 percent of the country's formal employment [3]. The horticultural sector in Kenya is well developed $^{1}$, but the potential of African Indigenous Vegetables (AIVs) has not been exploited, despite comprising a wide varieties of nutritious indigenous vegetable species $^{2}$ [14]. Even though AIVs have been cultivated in Kenya for many years, their promotion in terms of sustainable production and consumption is a recent phenomenon [15]. Gradual developments in the marketing of AIVs and an increase in awareness with regard to their consumption initiated their promotion. It is now widely known that AIVs are important sources of micronutrients, including vitamins, minerals, proteins and anti-oxidants that are adequate for normal growth and health [16]. However, production and consumption of AIVs have been adversely affected by agricultural risk and uncertainties such as production and marketing shocks (PMS), thus leading to food insecurity and malnutrition in smallholder households [17].

While the impacts of shocks on poverty have been widely studied in developing countries [18] [19], the decision to cope with simultaneous shocks as well as the extent of coping ${ }^{3}$ has not been thoroughly analysed. Therefore, this study aims at contributing to an understanding of the role of the main factors

${ }^{1}$ According to the Agriculture and Food Authority (AFA), flowers account for more than two thirds of Kenya's horticulture export earnings, while vegetables (such as French beans and runner beans) and fruit (such as avocado and mangoes) comprise around 20 percent and 10 percent respectively (KNBS, 2015).

${ }^{2}$ See [52] for more information.

${ }^{3}$ Coping refers to the ability to withstand and manage unexpected events, through ex-post strategies in order to sustain production, consumption, and livelihoods [18]. 
Table 1. Shocks faced by smallholder farmers and their effects.

\begin{tabular}{lll}
\hline Type of shock & Examples/Factors & Outcomes \\
\hline Production shocks & $\begin{array}{l}\text { Drought, shortage of water and rainfall } \\
\text { or temperature variability }\end{array}$ & $\begin{array}{l}\text { Lower yields, loss of productive } \\
\text { assets or income }\end{array}$ \\
Weather-related & $\begin{array}{l}\text { Flood, storm, unusually heavy rain, } \\
\text { landslides/erosion }\end{array}$ & $\begin{array}{l}\text { Total loss of productive assets and } \\
\text { income }\end{array}$ \\
Natural disasters & $\begin{array}{l}\text { Pest, diseases, contamination } \\
\text { Biological }\end{array}$ & $\begin{array}{l}\text { Lower yields, loss of income } \\
\text { Marketing shocks }\end{array}$ \\
Prices & $\begin{array}{l}\text { Changes in market demand and supply, } \\
\text { volatilities, hikes in fuel, input and } \\
\text { output prices }\end{array}$ & $\begin{array}{l}\text { Lower produce prices, and loss of } \\
\text { income, low quality products }\end{array}$ \\
\hline
\end{tabular}

Source: Authors' categorization of shocks.

(household, farm and institutional) in decision-making by AIV smallholder famers when faced with shocks, and consequently the extent to which they are able to cope. For this, we use a unique and comprehensive household survey data from rural and peri-urban smallholder farmers of African indigenous vegetables (AIV) in Kenya. The reason for using AIV farmers as a case study to assess the decision to cope with simultaneous shocks is two fold. On the one hand, since AIVs are recently promoted into both rural and urban markets, assessing AIV farmers' decisions to cope provides the ideal case for designing policies that have double positive effect of reducing farmers' vulnerability while supporting continued promotion of AIVs at the same time. On the other hand, AIVs are prone to the shocks considered in this study such as weather-related shocks of drought and shortage of water, as well as pests and diseases. Therefore, a sample of AIV farmers provides an ideal case for the investigation of the topic of shocks and coping strategies.

Greater knowledge about coping strategies would help design policies to prevent smallholder households from falling into poverty as well as protecting poor AIV farmers against the negative effects of shocks. This would be beneficial to the agricultural sector since it would complement the debate on AIVs and provide a basis for a reformulation of strategies geared towards the country's self-sufficiency in food and nutritional security. This study argues that farm location (rural or peri-urban) coupled with access to high-value markets (supermarkets, hospitals, schools, processing companies, large hotels and restaurants) are the major drivers and incentives for coping with shocks. It will contribute to the literature on the factors that influence the decision to cope with shocks by acknowledging the heterogeneity of households with regards to these variables.

\section{Literature Review: Adoption of Coping Strategies by Smallholder Farmers}

Much of the literature on shocks and coping strategies starts with the underlying 
lifecycle model which states that households aim to smooth consumption in order to maintain their marginal utility of consumption constant [20]. To smooth out consumption in times of shocks, additional resources are required to finance current consumption above the "shock-depleted" levels [21]. To do this, households may save when income is high and dissave when income is low, or in the absence of liquidity constraints households borrow when times are bad and pay back when it gets better. However, in developing countries where liquidity constraints are prevalent, saving and credit as well as formal insurance are not be common coping strategies and hence, limiting market-based coping strategies. In such cases, alternative coping strategies such as asset accumulation are used to compensate for future income fluctuations, as studied by [22] in infinite horizon models. In Zimbabwe and India, for instance, sale of livestock is used as part of a farming household's consumption smoothing strategy [23] [24]. The use of assets to buffer consumption in the face of an exogenous shock to income is found to be limited if the exogenous shock also threatens assets [25]. Furthermore, households also use informal insurance arrangements and social capital to cope with shocks. For instance in South African communities, households with social capital seem to be able to cope more effectively with weather shocks [26]. In Bangladesh, Ethiopia, Morocco, and Russia, community-level informal insurance arrangements are used to smooth food consumption [27].

Extremely poor households could be excluded from high-return activities because of lack of insurance, making them particularly vulnerable to shocks that frequently affect agricultural activities. This was evident among households in western Kenya as noted by [28]. This means engagement in low-return activities is pursued primarily, if not exclusively, by poorer households because they are desperate. They further concluded that the simultaneous diversification into low and high-return activities might reflect the high risk associated with high-return activities, which these households compensate for by venturing into low-return activities. Smallholder farmers also seek assistance from government and NGOs, to smooth consumption in times of shock. In Zimbabwe, for instance, government and NGO drought-relief schemes have provided substantial support to help maintain consumption levels against drought shocks [23]. [2] documented that, livelihood strategies and household resilience to food insecurity among smallholder farmers and pastoralists from the Northern drought-prone zone of Kenya are worse off because of their dramatically low levels of income and access to basic services. They, however, concluded that, by equipping communities with the ability to manage and respond to shocks in the early stages of a crisis, strategic livelihoods interventions allow for more timely and appropriate responses to disasters than is possible with typical emergency relief assistance.

A study by [29] on agricultural shocks and off-farm labour market decisions for rural households in Kenya revealed the existence of ex-ante off-farm labour supply responses to anticipated weather shocks to agricultural production. In addition, they found those households living in regions with a lower rainfall re- 
gime to be having a higher probability of participating in off-farm labour market and, conditional on participation, earn more from their engagements in off-farm work. This result shows participation in off-farm work as a long-term coping strategy for rural households towards responding to anticipated weather shocks to their agricultural operations. In the same line, household may also smooth out consumption by increasing labour supply and/or shift labour to other more direct income generating activities. For instance, shifts in labour from farm employment to off-farm employment in India [30], and increasing labour supply in Indonesia [21], are commonly used as coping strategies against shocks. The increase in labour even occurs during severe financial crises where real wages have collapsed, as in the case of Indonesia in the late 1990s [21].

There is a general consensus in the literature that households in developing countries are adversely affected by uninsured shocks, and that the corresponding damages are greater on poor farming households as they often lack the necessary resources to cope and recover from them [27] [31]. These households often face a combination of uninsured shocks and choose from a list of constrained coping strategies, which negatively affects their welfare. Severe idiosyncratic and covariate shocks are indicated in the literature as having a significant effect on the dynamics of household welfare. For instance, rainfall, household-specific crop failure, the occurrence of drought, pest and diseases, and illness are found to affect consumption in many Kenyan households [2] [13] [29] [32]. Even though the impact of shocks on poverty has been widely studied, the ability of smallholder households to cope with the occurrence of simultaneous shocks that affect their production and marketing activities has not been thoroughly analysed. Therefore, to fill this gap in the literature this study addresses two research questions:

1) Which socio-economic and institutional factors influence households' decision to undertake coping strategies in response to production and marketing shocks?

2) What are the determinants of the extent to which households' cope with simultaneous shocks?

For this, we use a unique data from AIV producers in Kenya. An understanding of shocks and their appropriate coping strategies would help in the design of relevant policies that can enhance the well-being of smallholder farming households by providing them with efficient and effective pathways of exiting poverty, while managing the negative effects of production and marketing shocks.

\section{Materials and Methods}

\subsection{Study Area and Data}

The study used data from the 2014 household survey that was conducted by Horticultural Innovations and Learning for Improved Nutrition and Livelihood in East Africa (HORTINLEA) project, in two rural (Kisii and Kakamega), and 
three peri-urban (Nakuru, Kiambu and Kajiado) counties of Kenya. Smallholder African indigenous vegetables (AIV) farming households who produce for both subsistence and commercialisation purposes were the main focus of this study. The focus vegetables included African nightshade (Solanum scabrum), spider plant (Cleome gynandra), amaranths (Amaranthus spp), cowpea (Vigna unguiculata) and Ethiopian kale (Brassica carinata). A structured survey questionnaire was administered to a total sample of 1232 AIV-producing households in rural (806) and peri-urban (426) areas identified using a multi-stage sampling technique. At village level, the respondents were randomly selected through a proportionate size sampling approach. The type of data collected in the main household survey included the household, capitals, institutional, and access related factors that were associated with their decision to cope with shocks and the extent of their ability to cope. Even though the HORTINLEA survey is not representative at a national level, the data provides a comprehensive overview of indigenous vegetable producers in rural and peri-urban areas. Given the randomized sampling method and the relatively large sample size in each county, results of the analysis performed on the survey data can be generalized to indigenous vegetable producers in rural and peri-urban areas in Kenya.

\subsection{The Empirical Model Specification}

Smallholder AIV farmers face the adverse effects of shocks and have to respond to them by selecting a coping strategy that will reduce the associated negative marginal effects. The farmers' selection of these strategies to cope with shocks could depend on the strategies selected earlier within a production cycle and thus informing their decisions about current and future selection. In this study, AIV farmers were asked whether or not they responded to shocks and to list the type of coping strategies that they used for each shock during the survey period ${ }^{4}$. Therefore, the decision to select a coping strategy carried a "yes" or "no" response, while the extent of coping with shocks required an answer with positive discrete numbers. The variable extent of coping is calculated by counting the number of coping strategies adopted by the household. This assumes that use of more number of coping strategies is somehow indicative of greater levels of coping. This is because production and marketing shocks require the use of inter-related coping strategies for an effective response for each type of shock. This assumption is supported by the work of [10] [18]. A limitation of using the number of coping strategies would be not accounting for the efficiency of individual coping strategies which could identify which strategy is more effective. This, however, is beyond the scope of this study.

Based on characteristics of the depend variables, we opt to use a count data

${ }^{4}$ In this context, the possibility of using simultaneous coping strategies against simultaneous shocks was acknowledged, therefore all the coping strategies used to cope with either production or marketing shocks during the 12 months prior to the survey were counted to represent the extent of their ability to cope with either type of shock. 
model, allowing for an independent estimation of the decision stage and outcome stage, simultaneously. This is because coping decision solely depends on the individual farmer, while the extent of coping depends on other conditioning factors such as assets, institutions and access to the necessary services. An econometric specification was employed based on the hurdle or two-part model, as proposed by [33], to investigate the determinants of coping as well as the extent of coping with shocks among smallholder AIV farmers. Two-part modelprovides a structural interpretation that agrees well with the two-step decision structure of the smallholders' coping process because it assumes that the two parts come from different data-generating processes and therefore the independent variables are allowed to have a different impact at each stage of the decision-making process. In addition, two-part model is derived from the negative binomial model for count data $[34]^{5}$. Therefore, following the recommendations of [33], and [34], the log-likelihood of the two-part model process was formulated as:

$$
\begin{aligned}
& l\left(\omega_{1}, \omega_{2}\right)=\sum_{i=1}^{N}\left\{f_{1}\left(y_{i}=0\right)\left[\log \left(\operatorname{Pr}_{1}\left(y_{i}=0 ; \omega_{1} \mid x_{i}\right)\right)\right]\right. \\
& \left.+f_{2}\left(y_{i}>0\right)\left[\log \left(\operatorname{Pr}_{1}\left(y_{i}>0 ; \omega_{1} \mid x_{i}\right)\right)+\log \left(\operatorname{Pr}_{2}\left(y_{i}=0 ; \omega_{2} \mid y_{i}>0, x_{i}\right)\right)\right]\right\}
\end{aligned}
$$

where $y_{i}, i=1 \ldots N$ represents the count-dependent variable with $y_{i}=0$ for zero response, and $y_{i}>0$ for positive responses of coping with shocks. $x_{i}$ represents a set of explanatory variables, while $\omega_{1}$ and $\omega_{2}$ are the vectors of unknown parameters associated with the two stages of the model. $P r_{1}\left(y_{i}=0 ; \omega_{1} \mid x_{i}\right)$ is the probability of zero counts (for those households who did nothing in response to shocks), $\operatorname{Pr}_{1}\left(y_{i}>0 ; \omega_{1} \mid x_{i}\right)=1-\operatorname{Pr}_{1}\left(y_{i}=0 ; \omega_{1} \mid x_{i}\right)$ is the probability that the threshold is crossed, and $\operatorname{Pr}_{2}\left(y_{i}>0 ; \omega_{2} \mid y_{i}>0, x_{i}\right)$ denotes the truncated-at-zero distribution for the positive responses (extent of coping with shocks). $f_{1}($.$) represents the process of generating zeros where the$ household is not coping with shocks, while, $f_{2}($.$) represents the process of$ generating the positive responses $(\mathrm{N})$, describing the extent of coping with shocks. Two-part model is advantageous because of its computational approach where, if the two stages are independent, the log-likelihood can be factorised as the sum of two log-likelihood functions, and therefore the model parameters can be estimated by maximising the two terms separately [34] [35] [36].

Empirically, the probability distribution of two-part model in the context of the decision taken by smallholder AIV farmers and the extent of coping with shocks is written as:

$$
g\left(y_{i}\right)=\left\{\begin{array}{l}
f_{1}(0) \text { if } y_{i}=0 \text { Coping }(\text { Decision) } \\
\frac{1-f_{1}(0)}{1-f_{2}(0)} f_{2}\left(y_{i}\right) \text { if } y_{i}=1,2,3, \cdots, N \text { Extent of Coping(outcome) }
\end{array}\right\}
$$

where $g\left(y_{i}\right)$ represents the truncated at zero distribution for the positive re-

${ }^{5}$ See [34] for more on NBM and TPM. 
sponse. In this context, two-part model was estimated using a logit model in the decision part and a geometric model (generalised linear model (GLM)) in the second part to determine farmers' decision to cope with shocks. This is where the predicted number of coping strategies used against shocks was modelled with the assumption of a truncated negative binomial distribution. Finally, a set of explanatory variables are included in the empirical model based on literature review [10] [18] [23] [25] [29] [37] [38] [39] [40], where household, socioeconomic and institutional factors have been found as playing a vital role in conditioning smallholder farmers' decisions and the extent of their response to agricultural risks.

\section{Results and Discussion}

\subsection{Descriptive Statistics}

Smallholder AIV farmers were interviewed whether they faced shocks in $2013 / 2014$ production and marketing season. The results indicated that 66.4 percent of the surveyed AIV farmers faced at least one production shock, while 11.8 percent of the same group of farmers faced at least one marketing shock (Table 2). This shows that households are usually faced with simultaneous shocks, forcing them to spread out available coping strategies across time. For production shocks in particular, 45 percent of sampled households had been exposed to crop pest and diseases, 40 percent to crop failures, 32.9 percent to unusually heavy rains, 27.1 percent to drought, and 12 percent to water shortages. Among the marketing shocks, 63.5 percent of the interviewed farmers responded positively to having been exposed to food price increases and 40.7 percent to input price increases, while a further 10.3 percent had been exposed to fuel price increases. It was also evident that 23.1 percent and 17.9 percent of the interviewed farmers responded by doing nothing when exposed to production shocks and marketing shocks, respectively. This could be due to either households are too poor/not able to do anything against the shock, or that they already had an ex-ante coping strategy in place and hence the effect of the shock was minimal. In both cases, the percentages of households who implemented at least one coping strategy compared with those who did nothing at all in response to shocks were further assessed and compared with regards to their socioeconomic and institutional characteristics (Table 2).

Those smallholder farmers who faced production and marketing shocks were subsequently asked whether they took active action in response to these shocks. The results indicated that, 76.9 percent and 82.1 percent of the interviewed respondents who faced production and marketing shocks respectively managed to adopt various coping strategies. Further, the coping strategies used by smallholder AIV farmers were informal and could be divided into three categories: behaviour-based strategies (working more, diversifying agricultural portfolios, reducing consumption and substituting crops), asset-based strategies (selling assets, using savings and insurance), and assistance-based strategies (borrowing and seeking help). However, there can be short and long-term effects of these 
Table 2. Household level descriptive statistics by coping and non-coping with production and marketing shocks $(\mathrm{n}=1232)$.

\begin{tabular}{|c|c|c|c|c|c|c|c|c|c|c|}
\hline \multirow{3}{*}{ Variable } & \multicolumn{5}{|c|}{ Production Shocks } & \multicolumn{5}{|c|}{ Marketing Shocks } \\
\hline & \multicolumn{2}{|c|}{ Coping $(n=629)$} & \multicolumn{2}{|c|}{$\begin{array}{l}\text { Non coping } \\
(\mathrm{n}=189)\end{array}$} & \multirow[t]{2}{*}{$\mathrm{Chi}^{\mathrm{a}} / \mathrm{t}^{- \text {test }^{\mathrm{b}}}$} & \multicolumn{2}{|c|}{$\begin{array}{c}\text { Coping } \\
(\mathrm{n}=119)\end{array}$} & \multicolumn{2}{|c|}{$\frac{\text { Non coping }}{(\mathrm{n}=26)}$} & \multirow[t]{2}{*}{$\mathrm{Chi}^{\mathrm{a}} / \mathrm{t}^{- \text {test }}$} \\
\hline & Mean & Std. Dev. & Mean & Std. Dev. & & Mean & Std. Dev. & Mean & Std. Dev. & \\
\hline \multicolumn{11}{|l|}{ Human capital } \\
\hline Household size & 5.99 & 2.257 & 5.10 & 2.191 & $4.813^{* * *}$ & 5.99 & 1.989 & 5.23 & 2.503 & $1.683^{*}$ \\
\hline Gender & 0.80 & 0.399 & 0.79 & 0.406 & 0.053 & 0.82 & 0.383 & 0.77 & 0.430 & 0.415 \\
\hline Age & 49.29 & 12.231 & 50.11 & 13.495 & -0.787 & 51.13 & 12.039 & 52.96 & 11.827 & -0.703 \\
\hline Marital status & 0.80 & 0.403 & 0.79 & 0.406 & 0.007 & 0.82 & 0.383 & 0.77 & 0.430 & 0.415 \\
\hline Education & 9.15 & 4.522 & 9.51 & 4.664 & -0.940 & 9.07 & 4.286 & 9.85 & 4.451 & -0.834 \\
\hline \multicolumn{11}{|l|}{ Social capital } \\
\hline Land tenure & 0.91 & 0.280 & 0.89 & 0.315 & 1.114 & 0.90 & 0.302 & 1.00 & 0.000 & $2.858^{\star}$ \\
\hline Member to a farmer group & 0.44 & 0.496 & 0.32 & 0.467 & $8.617^{\star * *}$ & 0.41 & 0.494 & 0.31 & 0.471 & 0.969 \\
\hline \multicolumn{11}{|l|}{ Natural capital } \\
\hline Rural location & 0.78 & 0.413 & 0.49 & 0.501 & $62.104^{\star * *}$ & 0.87 & 0.343 & 0.58 & 0.504 & $11.730^{* * *}$ \\
\hline Fertile soil & 0.50 & 0.500 & 0.58 & 0.495 & $3.641^{*}$ & 0.53 & 0.501 & 0.38 & 0.496 & 1.790 \\
\hline Steep land slope & 0.42 & 0.494 & 0.33 & 0.471 & $5.444^{* *}$ & 0.39 & 0.491 & 0.38 & 0.496 & 0.100 \\
\hline \multicolumn{11}{|l|}{ Physical capital } \\
\hline Distance to market & 2.36 & 2.418 & 2.39 & 2.464 & -0.168 & 2.04 & 1.796 & 2.69 & 1.644 & -1.696 \\
\hline Distance to agro-vet & 2.24 & 2.128 & 1.96 & 1.889 & $1.656^{*}$ & 2.01 & 2.366 & 2.58 & 2.403 & -1.102 \\
\hline Type of irrigation system & 0.14 & 0.350 & 0.20 & 0.398 & $3.076^{*}$ & 0.10 & 0.302 & 0.27 & 0.452 & $5.314^{* *}$ \\
\hline \multicolumn{11}{|l|}{ Financial capital } \\
\hline Total household income (log) & 16.17 & 0.223 & 16.17 & 0.250 & 0.266 & 16.12 & 0.384 & 16.27 & 0.236 & -1.928 \\
\hline Off-farm income & 0.23 & 0.419 & 0.35 & 0.478 & $11.346^{* * *}$ & 0.23 & 0.421 & 0.46 & 0.508 & $5.975^{* *}$ \\
\hline Total livestock units (TLU) & 0.75 & 0.545 & 0.82 & 0.661 & 0.007 & 0.67 & 0.550 & 0.60 & 0.649 & 0.643 \\
\hline Grading of AIV & 0.34 & 0.475 & 0.39 & 0.489 & 1.471 & 0.39 & 0.491 & 0.42 & 0.504 & 0.070 \\
\hline Number of farm enterprises & 5.95 & 2.255 & 5.01 & 2.312 & $5.025^{\star * *}$ & 6.24 & 2.786 & 4.88 & 1.558 & $2.402^{* *}$ \\
\hline Land size (log) & 0.30 & 1.026 & 0.28 & 0.973 & 0.226 & 0.35 & 0.926 & 0.24 & 1.014 & 0.524 \\
\hline \multicolumn{11}{|l|}{$\begin{array}{c}\text { Institution and access-related } \\
\text { variables }\end{array}$} \\
\hline Credit services & 0.22 & 0.412 & 0.14 & 0.351 & $4.902^{* *}$ & 0.18 & 0.390 & 0.15 & 0.368 & 0.140 \\
\hline Access to information & 0.37 & 0.484 & 0.40 & 0.492 & 0.559 & 0.40 & 0.493 & 0.35 & 0.485 & 0.293 \\
\hline High-value market & 0.18 & 0.384 & 0.13 & 0.334 & $2.891^{*}$ & 0.14 & 0.351 & 0.04 & 0.196 & 2.139 \\
\hline Warning on shocks & 0.18 & 0.388 & 0.14 & 0.351 & 1.740 & 0.18 & 0.390 & 0.15 & 0.368 & $3.427^{\star}$ \\
\hline Contract farming & 0.08 & 0.266 & 0.07 & 0.254 & 0.119 & 0.10 & 0.302 & 0.15 & 0.368 & 0.611 \\
\hline Certification & 0.34 & 0.475 & 0.20 & 0.402 & $13.478^{* * *}$ & 0.28 & 0.450 & 0.27 & 0.452 & 0.007 \\
\hline Extension services & 1.74 & 3.135 & 0.95 & 2.130 & $3.226^{* * *}$ & 1.72 & 3.234 & 1.23 & 2.405 & 0.732 \\
\hline
\end{tabular}

$\mathrm{a}$ and $\mathrm{b}$ are statistical tests for categorical and continuous variables respectively; ${ }^{* * *}(\mathrm{p}<0.01),{ }^{* *}(\mathrm{p}<0.05),{ }^{*}(\mathrm{p}<0.10)$. 
coping strategies (depletion of available resources), especially among those households that have low consumption growth, limited savings, and limited access to non-exploitative credit. In this study, the total number of coping strategies applied in response to shocks was used to measure the extent to which smallholder AIV farmers coped with shocks. Consequently, the descriptive result shows that households either do nothing (zero coping strategy) or adopt a positive (one or more coping strategies) complementary coping strategies. As shown in Figure 1, for production shocks, the extent of coping ranged from 0 to 11 coping strategies, while for marketing shocks it ranged from 0 to 6 coping strategies.

\subsection{Determinants of the Decision to Cope with Production and Marketing Shocks}

This section presents and discusses the results from the two-part model (TPM) used to determine the main factors behind the decision to cope, and the extent of coping with production or marketing shocks. In order to ensure that our results are robust, we estimate a multicollinearity test (variance inflation factors (VIF), and correlation matrix) for the explanatory variables. The results indicate an absence of multicollinearity between the explanatory variables (average VIF of 1.32). Further, we estimated a standard negative binomial model to test for overdispersion in the data and the results showed a significant likelihood ratio test of an overdispersion parameter (alpha greater than zero) and hence demonstrated the presence of overdispersion. This result indicates that negative binomial model was superior to the ordinary poisson model and hence confirmed the use of a two-part model because it was derived from the negative binomial model for count data.

The results on the parameter estimates from the two-part model are presented in Table 3. The logistic regression results showed that institutions and access-related variables were the main significant factors informing smallholder AIV farmers' decision to cope with shocks. In this category, we find that access to high-value market chains (supermarkets, processing companies, large hotels

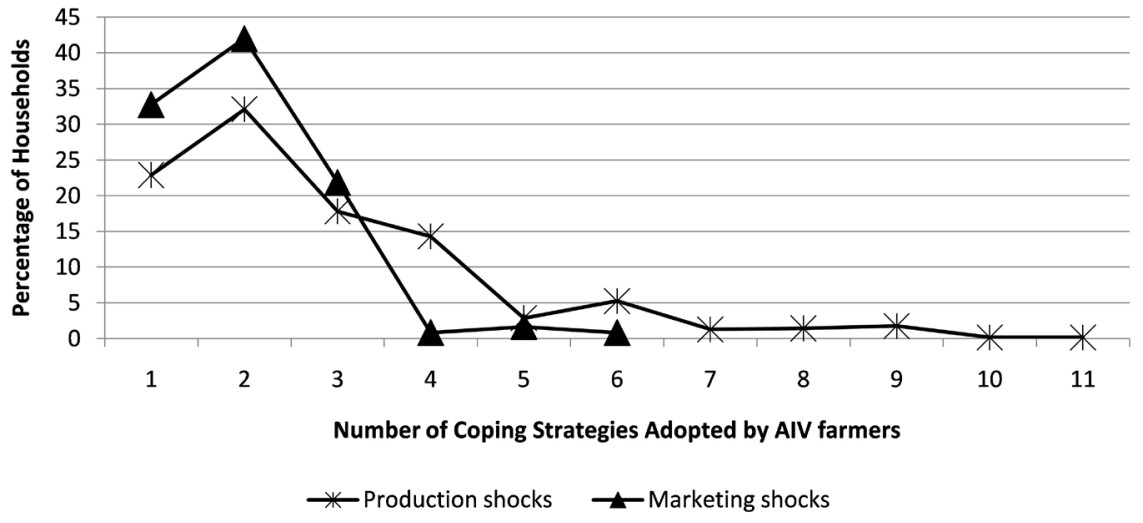

Figure 1. Extent to which AIV farmers cope with production and marketing shocks. 
Table 3. Parameter estimates from the estimation of the two-part model for the decision to cope and extent of coping with PMS.

\begin{tabular}{|c|c|c|c|c|c|c|c|c|}
\hline \multirow{3}{*}{ Variable } & \multicolumn{4}{|c|}{ Coping with production shocks } & \multicolumn{4}{|c|}{ Coping with marketing shocks } \\
\hline & \multicolumn{2}{|c|}{ First part (Logit) } & \multicolumn{2}{|c|}{$\frac{\text { Second Part }}{\text { (Geometric) }}$} & \multicolumn{2}{|c|}{ First part (Logit) } & \multicolumn{2}{|c|}{ Second Part (Geometric) } \\
\hline & Coef. (Std. Err.) & $\begin{array}{c}\text { Marginal } \\
\text { effects }\end{array}$ & $\begin{array}{c}\text { Coef. } \\
\text { (Std. Err.) }\end{array}$ & $\begin{array}{c}\text { Marginal } \\
\text { effects }\end{array}$ & $\begin{array}{c}\text { Coef. } \\
\text { (Std. Err.) }\end{array}$ & $\begin{array}{l}\text { Marginal } \\
\text { effects }\end{array}$ & $\begin{array}{c}\text { Coef. } \\
\text { (Std. Err.) }\end{array}$ & $\begin{array}{c}\text { Marginal } \\
\text { effects }\end{array}$ \\
\hline \multicolumn{9}{|l|}{ Human capital } \\
\hline Household size & $0.0749(0.0261)$ & $0.0196^{* * *}$ & $0.0330(0.0242)$ & 0.0191 & $0.0800(0.0902)$ & 0.0139 & $-0.0030(0.0089)$ & -0.0013 \\
\hline Gender & $0.0347(0.1876)$ & 0.0091 & $0.1516(0.1866)$ & 0.0880 & $0.2269(0.6725)$ & 0.0394 & $0.0350(0.0680)$ & 0.0153 \\
\hline Age & $-0.0099(0.0044)$ & $-0.0012^{\star}$ & $-0.0073(0.0042)$ & $-0.0043^{\star}$ & $-0.0209(0.0165)$ & -0.0036 & $0.0014(0.0015)$ & 0.0006 \\
\hline Marital status & $-0.1835(0.1853)$ & -0.0478 & $-0.1401(0.1851)$ & -0.0813 & $0.2619(0.7801)$ & 0.0455 & $-0.0113(0.0674)$ & -0.0050 \\
\hline Education & $-0.0035(0.0130)$ & -0.0009 & $-0.0231(0.0123)$ & -0.0134 & $-0.0438(0.0453)$ & -0.0076 & $0.0015(0.0045)$ & 0.0007 \\
\hline \multicolumn{9}{|l|}{ Social capital } \\
\hline Land tenure & $0.7258(0.2006)$ & $0.0498^{* * *}$ & $0.4363(0.1613)$ & $0.2533^{* * *}$ & $-0.1673(0.4163)$ & 0.1107 & $0.0393(0.3390)$ & 0.0303 \\
\hline $\begin{array}{l}\text { Membership to farmer } \\
\text { groups }\end{array}$ & $-0.1258(0.2153)$ & -0.0329 & $0.2369(0.1166)$ & $0.1375^{\star *}$ & $-0.3599(0.3791)$ & -0.0625 & $-0.0368(0.0425)$ & -0.0160 \\
\hline \multicolumn{9}{|l|}{ Natural capital } \\
\hline Rural location & $0.8323(0.1551)$ & $0.2177^{\star * *}$ & $0.9952(0.1537)$ & $0.5777^{* * *}$ & $0.2946(0.5861)$ & 0.0512 & $0.2098(0.0560)$ & $0.0915^{* * *}$ \\
\hline Land size & $-0.0065(0.0527)$ & -0.0017 & $0.0616(0.0482)$ & 0.0358 & $0.1482(0.1701)$ & 0.0257 & $0.0135(0.0176)$ & 0.0059 \\
\hline Fertile soil & $-0.2638(0.1277)$ & $-0.0281^{\star *}$ & $-0.2023(0.1049)$ & $-0.1174^{\star *}$ & $0.7517(0.3509)$ & $0.1305^{\star *}$ & $0.0485(0.0382)$ & 0.0211 \\
\hline Steep slope & $-0.3298(0.1523)$ & $-0.0863^{\star *}$ & $-0.3789(0.1436)$ & $-0.2199^{\star * *}$ & $-0.4480(0.5462)$ & -0.0778 & $-0.0104(0.0523)$ & -0.0045 \\
\hline \multicolumn{9}{|l|}{ Physical capital } \\
\hline Distance to market & $0.0211(0.0260)$ & 0.0055 & $0.0302(0.0212)$ & 0.0175 & $-0.1444(0.0973)$ & -0.0251 & $-0.0043(0.0077)$ & -0.0019 \\
\hline $\begin{array}{c}\text { Distance to nearest } \\
\text { agro-vet }\end{array}$ & $0.0372(0.0303)$ & 0.0097 & $-0.0095(0.0147)$ & -0.0055 & $-0.1005(0.0656)$ & -0.0174 & $-0.0015(0.0053)$ & -0.0007 \\
\hline Type of irrigation system & $0.0214(0.1742)$ & 0.0056 & $-0.0709(0.1613)$ & -0.0411 & $-1.4039(0.5586)$ & $-0.2438^{\star * *}$ & $-0.0711(0.0588)$ & -0.0310 \\
\hline \multicolumn{9}{|l|}{ Financial capital } \\
\hline Total household income & $-0.1255(0.2300)$ & -0.0328 & $0.0459(0.2053)$ & 0.0267 & $-0.5341(0.4915)$ & -0.0927 & $-0.0979(0.0718)$ & -0.0427 \\
\hline Off-farm income & $-0.2735(0.1476)$ & $-0.2148^{*}$ & $-0.2048(0.1211)$ & $-0.1189^{\star}$ & $-1.0040(0.4041)$ & $-0.1743^{\star * *}$ & $0.0360(0.0441)$ & 0.0157 \\
\hline TLU & $-0.1513(0.0908)$ & $-0.0396^{*}$ & $-0.1697(0.0898)$ & $-0.0985^{*}$ & $0.4531(0.2994)$ & 0.0787 & $-0.0578(0.0327)$ & $-0.0252^{*}$ \\
\hline Grading of AIV & $-0.1427(0.1096)$ & -0.0373 & $-0.0572(0.1060)$ & -0.0332 & $-0.1334(0.3355)$ & -0.0232 & $0.0649(0.0386)$ & $0.0283^{*}$ \\
\hline $\begin{array}{c}\text { Number of farm } \\
\text { enterprises }\end{array}$ & $0.0181(0.0269)$ & 0.0048 & $0.0514(0.0252)$ & $0.0298^{\star *}$ & $0.1466(0.1031)$ & 0.0255 & $0.0162(0.0092)$ & $0.0070^{*}$ \\
\hline \multicolumn{9}{|l|}{$\begin{array}{l}\text { Institution and } \\
\text { access-related variables }\end{array}$} \\
\hline Access to credit & $0.4052(0.1446)$ & $0.1060^{\star * \star}$ & $0.2949(0.1311)$ & $0.1712^{\star \star}$ & $-0.2549(0.4712)$ & -0.0443 & $0.0159(0.0477)$ & 0.0069 \\
\hline Access to information & $-0.0529(0.1227)$ & -0.0138 & $0.3118(0.1628)$ & $0.0971^{*}$ & $0.6258(0.4265)$ & 0.1087 & $0.0974(0.0418)$ & $0.0425^{\star *}$ \\
\hline High-value market access & $0.4224(0.1537)$ & $0.1105^{\star * *}$ & $-0.1332(0.1354)$ & -0.0773 & $0.8768(0.5730)$ & 0.1522 & $-0.0303(0.0493)$ & -0.0132 \\
\hline $\begin{array}{c}\text { Access to warning on } \\
\text { shocks }\end{array}$ & $0.2915(0.1718)$ & $0.0217^{*}$ & $0.1566(0.1391)$ & 0.0909 & $1.0411(0.7895)$ & 0.1808 & $-0.0127(0.0507)$ & -0.0055 \\
\hline Contract farming & $-0.0084(0.2153)$ & -0.0022 & $-0.1314(0.1916)$ & -0.0763 & $-0.1500(0.5883)$ & -0.0260 & $0.0765(0.0698)$ & 0.0334 \\
\hline Certification & $0.3368(0.1266)$ & $0.0881^{\star * *}$ & $0.1432(0.1174)$ & 0.0831 & $-0.1505(0.4088)$ & -0.0261 & $-0.0667(0.0427)$ & -0.0291 \\
\hline Access to extension & $0.1114(0.0321)$ & $0.0292^{\star * *}$ & $0.1175(0.0250)$ & $0.0682^{* * *}$ & $0.1758(0.1586)$ & 0.0350 & $0.0090(0.0091)$ & 0.0039 \\
\hline Constant & $1.8382(3.7592)$ & & $-0.2345(3.3583)$ & & $9.5290(8.3085)$ & & $1.4512(1.2209)$ & \\
\hline \multicolumn{9}{|c|}{ Regression diagnostics for the two-part model } \\
\hline Number of observation & 1232 & & 629 & & 1232 & & 119 & \\
\hline Log likelihood & -762.8971 & & -1219.4888 & & -364.8154 & & -143.1130 & \\
\hline LR chi2 (26) & 181.57 & & & & 52.76 & & & \\
\hline $\mathrm{AIC} / \mathrm{BIC}$ & & & $3.9634 / 2100.375$ & & & & $2.8590 /-362.471$ & \\
\hline
\end{tabular}

${ }^{* * *}(\mathrm{p}<0.01),{ }^{* *}(\mathrm{p}<0.05),{ }^{*}(\mathrm{p}<0.10)$. 
and restaurants) is a major determinant in the decision to cope with production shocks. This is attributed to the timely requirements of specific quantity and quality standards that are driven by consumer preferences on high-value markets. Furthermore, access to high-value market chain enables farmers to plan their production efficiently and effectively, and even facilitates access to financial credit from formal institutions, boosting their ability to cope with production shocks. Consistent with [41], we found that contact with extension agents significantly increased the probability of coping with production shocks. Access to extension services, specifically field visits, is a powerful tool that can be used to encourage farmers to change and build their resilience and capacity to deal with shocks. In addition, frequent interactions between farmers and extension agents expose farmers to modern farming technologies and hence stimulate communication and reflections on their associated benefits. In line with [10], our study found that smallholder AIV farmers who used modern types of irrigation systems were less likely to be able to cope with marketing shocks. Access to irrigation is a commonly used variable in the literature about shocks and coping strategies [10] [39]. In our study, particular attention was paid to the type of irrigation system that AIV producers use for production ${ }^{6}$. This is because modern irrigation technologies save water and are therefore efficient and effective at combating the negative effects of shocks when compared to traditional types. Further, consistent with [42], we find that certified AIV farmers were more likely to cope with production shocks, and hence gaining access to niche markets in an efficient and effective manner.

Access to financial capital in general and credit services in particular was found to significantly and positively determine the decision to cope with production shocks. This finding supports the argument that credit access enables farming households to accumulate assets, and invest in new farming technologies that gives them a solid basis for coping with production shocks [25] [41]. With regards to total livestock units (TLU), and in contrast to [43], farmers with higher TLU were found to be less likely to cope with production shocks. This could be because farmers with higher TLU were less risk averse. Hence, coping ability/behaviour in the face of the adverse impacts of shocks and stresses varied considerably between farmers who had access to or owned assets such as livestock. These findings are in line with that of [12], where smallholder AIV farmers who have off-farm income are less likely to cope with marketing shocks. This implies that smallholder farmers who have off-farm income opportunities were less likely to face agricultural production and marketing shocks because they did not rely entirely on such activities for their household income and food. This entirely depended on the proportion of off-farm income to total household income, and the opportunity cost of being engaged in farming activities because

${ }^{6}$ In this study, modern types of irrigation systems include drip, sprinkler and pot irrigation methods, while the traditional irrigation types include basin, furrow and strip irrigation methods. 
such opportunities act as an alternative to agricultural production activities. Furthermore, access to off-farm income-generating opportunities is also a way of hedging against shocks, especially when those opportunities are not perfectly correlated to agricultural yields.

The results showed that human capital was a significant factor in informing the decision to cope with shocks. With regards to household size and consistent with other findings [37] [44], we found that households with higher number of family members were found to be more likely to cope with production shocks. Therefore, depending on the proportion of household members who were able to participate in farm activities, household food demand and the opportunity cost of off-farm income, farmers with a higher number of household members were more likely to engage in coping strategies that are labour intensive and/or off-farm opportunities as a concurrent coping strategy. Access and entitlement to natural capital significantly determined the decisions taken by smallholder AIV farmers to cope with shocks. With regards to the location of smallholder farms, we found that farmers from rural areas were more likely to implement coping strategies to production shocks. This is because the majority of them were entirely depending on farming as their main livelihood since farming land in rural areas is more productive, with higher intensification and management of risk that is more pronounced, than its counterpart in urban areas. In addition, water availability could be a driving factor in the decision to cope more effectively with production shocks in rural areas.

Smallholder farmers with steeply sloping land were found to be less likely to cope with production shocks. In addition, farmers with fertile land were less likely to cope with production shocks, but were more likely to make decisions to cope with marketing shocks. This is because such land requires fewer inputs to achieve a higher level of marketed output. These findings are consistent with those of [45] who note that there is a positive relationship between fertile, relatively flat land and the adoption of farm-based technologies to manage shocks. Access to physical capital by smallholders makes their labour more productive, and hence extends their opportunities for income generation, thus leading to increased certainty and choice [46]. In this category and consistent with [47], we find that access to modern irrigation systems decreased the probability of smallholder farmers coping with marketing shocks. Smallholder farmers who have access to modern irrigation technology are more likely to increase their household consumption and asset accumulation, and hence reduce their level of poverty. These groups of farmers are producing throughout the year, and therefore during adverse production conditions they make more profit from higher prices of marketed outputs due to low vegetable supply during such periods.

\subsection{Determinants of the Extent of Coping with Production and Marketing Shocks}

The study results of the parameter estimates from the second part of the 
two-part model are presented in Table 3 . The availability of relevant institutions and access-related services are the main key variables that determine the extent of coping with shocks among smallholder AIV farmers in Kenya. In this respect, and consistent with studies of [40] and [48], our findings revealed that farmers who have access to credit services are more likely to increase their extent of coping with production shocks. This is because access to credit services relaxes liquidity constraints and thus enhances the adoption of appropriate technology that would reduce the impacts of production shocks.

In line with [49], we find that farmers who have access to extension contacts were more likely to increase the extent of their coping with production shocks. The higher the number of contacts with extension providers, the more information acquired regarding AIV production, and hence the greater the number of options for dealing with the negative effects of production shocks. Access to market information significantly determined the extent to which farmers coped with marketing shocks. This implies that households who had access to market information were more likely to increase their extent of coping strategies with both production and marketing shocks. Access to market information by farmers specifically regarding farm produce and input markets is necessary to act as an incentive to increase the level and intensity of coping with shocks because it enables them to explore lucrative income-generating opportunities from modern farm technologies and high-value market chains. For instance, high-value market access requires formal contracts and meeting food safety standards which require effective and efficient access to relevant information [50].

Natural factors played an important role in determining the extent to which smallholder AIV farmers coped with shocks. For instance, farmers from rural areas were more likely to increase their extent of coping with both production and marketing shocks. This implied that farmers from rural areas put more effort into the selection and implementation of more coping strategies than their counterparts from peri-urban areas because of the importance (as main source of livelihood) of farming to total household income. Additionally, farmers from rural areas had limited off-farm income opportunities, unlike those from peri-urban areas who are moving out of agriculture to exploit various lucrative off-farm income opportunities in tandem that are created by urban developments. Consistent with [45], we find that farmers with steep slope and fertile land parcels were found to be less likely to increase the extent to which they coped with production shocks. This could be because this group of farmers sees no sense of increasing the number of coping strategies if they could achieve the same yield without necessarily adjusting the amount of inputs used.

Social capital is an important component among smallholder AIV farmers since it significantly determined their extent of coping with shocks. With respect to land ownership, and contrary to [41], we find that farmers who fully owned their parcels of land were found to be more likely to increase their extent of coping with production shocks. Farmers who own more of the productive re- 
sources were more likely to protect their household food expenditure at the expense of non-food expenditure by adopting coping strategies (such as borrowing from formal institutions) that require land ownership rights for collateral purposes. In line with [51], our results suggest that access to farmers' groups by smallholder farmers significantly determines and increases the probability of using more coping strategies against production shocks. Being a member of a farmers' group is an effective resource that can be used to mitigate the effects of production shocks because it enables farmers to build social networks which serve as important risk-coping mechanisms.

Financial capital was a crucial factor that significantly determined the number of coping strategies used by smallholder AIV farmers when responding to shocks. With regards to off-farm income and consistent with [29], access to off-farm income was found to reduce the extent of coping with production shocks. This implies that when farmers have access to off-farm income, they tend to maximise their household needs through such possibilities while relying less and less on farm outputs. Moreover, smallholder farmers who graded their vegetables before selling them were more likely to increase their extent of coping with marketing shocks. This implies that the grading of AIVs into different categories, based on the attributes preferred by their consumers, was more likely to positively influence the number of coping strategies used against marketing shocks.

Similar to the findings of [49], the present study found that if farmers operated a greater number of farm enterprises, the extent of coping with production shocks is increased. This means that farm enterprise diversification is a common risk management tool among smallholder farmers, but largely depends on biophysical, social and institutional factors in informing their decision to use more coping strategies. Smallholder farmers always prefer to invest in farm enterprises that offer higher returns. However, such farm enterprises are risky and demand higher resource investment capacities in terms of endowment and entitlements for start-up. Therefore, smallholder farmers who have higher incomes are more likely to get involved in more lucrative farm enterprises, while low-income and risk-averse households will be confined to low return farm enterprises.

Finally, human capital factors significantly determined the number of coping strategies used by smallholder AIV farmers to cope with production shocks. In contrast with [38], older farmers were found to be less likely to increase the extent to which they coped with production shocks. This implies that as the farmers aged, there was less likelihood of increasing the extent to which they coped with production shocks because of the decline in their planning horizon. In contrast, younger farmers were likely to be more flexible because they are familiar with modern communication technologies currently being used to disseminate agricultural information, including choices of coping strategies to deal with shocks.

\section{Conclusions}

This study used a detailed household-level data and a two-part count data model 
to analyse the determinants of the decision, and extent of coping with production and marketing shocks by smallholder AIV farmers in Kenya. We observed that more than two thirds of the farmers interviewed had active strategies to cope with shocks, but the majority of the coping strategies were not based on market-related insurance mechanisms. Thus, formal and market-based insurance mechanisms against such shocks should be put in place to reduce the opportunity costs incurred when using informal and unsustainable strategies. The results of the two-part model identified access to high-value market chains and critical services such as credit, extension services, market information and farmers' groups as the most important factors in the decision to cope and the extent of coping strategies by smallholder AIV households. These results have significant policy implications. It is important to design policies that facilitate access to services with the required information on appropriate, location-specific coping strategies. There is also a need to promote credit markets through the implementation of mobile phone-based banking services for easy accessibility in remote rural areas where formal financial services are limited. These specific policies will go a long way towards improving the level of coping with production and marketing shocks by enabling smallholder AIV farmers to overcome information and resource constraints. Additionally, access to necessary information and relevant resources would lead to the implementation of appropriate coping strategies that stabilise AIV yields and ensure consistent supplies to high-value market chains, thus enabling smallholder farmers to successfully respond to production and marketing shocks.

The positive impact of membership of farmers' groups on farmers' ability to cope with production shocks suggests that policies that encourage the establishment of social capital among smallholder AIV farmers should be efficiently and effectively devised in a sustainable manner. This is because they act as a necessary and sufficient conduit for information dissemination, and provide mutual support to help smallholder farmers' access critical services and resources needed to implement relevant and appropriate coping strategies to deal with shocks. Finally, the importance of access to high-value market chains and certification in the decision to cope with production shocks suggests the need for policies that support farmers in securing contracts for direct supply to high-value market chains. This will enable them to shift directly to a marketed-oriented form of production, and furthermore encourage them to diversify to high-return farm enterprises so that they can reduce the opportunity costs of on-farm labour and resource allocation and thus lock in the labour required to cope with shocks.

\section{Acknowledgements}

We would like to acknowledge the financial support for the study to the German Federal Ministry of Education and Research (BMBF) and the German Federal Ministry of Economic Cooperation through Horticultural Innovation and Learn- 
ing for Improved Nutrition and Livelihood in East Africa (HORTINLEA) project. We would also like to appreciate the team who played a role from the project design, survey, data entry, and analysis for their efforts. The opinions conveyed herein are exclusively those of the authors and not of the affiliated institutions.

\section{References}

[1] Nagayet, O. (2005) Small Farms: Current Status and Key Trends. In: IFPRI, Ed., The Future of Small Farms. Proceedings of a Research Workshop, International Food Policy Research Institute, Washington DC, 355-367.

[2] Alinovi, L., D’Errico, M., Mane, E. and Romano, D. (2010) Livelihoods Strategies and Household Resilience to Food Insecurity: An Empirical Analysis to Kenya. European Report of Development, Dakar.

[3] FAO (2016) Characterization of the Agricultural Drought Prone Areas at a Global Scale. http://www.fao.org/3/a-i5764e.pdf

[4] Herberich, D.H. and List, J.A. (2012) Digging into Background Risk: Experiments with Farmers and Students. American Journal of Agricultural Economics, 94, 457-463. https://doi.org/10.1093/ajae/aar070

[5] Dube, O., Garcia Ponce, O. and Thom, K. (2014) From Maize to Haze: Agricultural Shocks and the Growth of the Mexican Drug Sector. Center for Global Development Working Paper (355). https://doi.org/10.2139/ssrn.2457186

[6] Dercon, S. (2004) Growth and Shocks: Evidence from Rural Ethiopia. Journal of Development Economics, 74, 309-329. https://doi.org/10.1016/j.jdeveco.2004.01.001

[7] Elbers, C., Gunning, J. and Kinsey, B. (2007) Growth and Risk. Methodology and Micro Evidence. Wold Bank Economic Review, 21, 1-20.

https://doi.org/10.1093/wber/lhl008

[8] Gloede, O., Menkhoff, L. and Waibel, H. (2013) Shocks, Individual Risk Attitude, and Vulnerability to Poverty among Rural Households in Thailand and Vietnam.

[9] FAO (2008) Climate Change and Food Security: A Framework Document. Rome. http://www.fao.org/docrep/010/k2595e/k2595e00.htm

[10] Salazar-Espinoza, C., Jones, S. and Tarp, F. (2015) Weather Shocks and Cropland Decisions in Rural Mozambique. Food Policy, 53, 9-21.

https://doi.org/10.1016/j.foodpol.2015.03.003

[11] Ellis, F. (2000) The Determinants of Rural Livelihood Diversification in Developing Countries. Journal of Agricultural Economics, 51, 289-302. https://doi.org/10.1111/j.1477-9552.2000.tb01229.x

[12] Ito, T. and Kurosaki, T. (2009) Weather Risk, Wages in Kind, and the Off-Farm Labor Supply of Agricultural Households in a Developing Country. American Journal of Agricultural Economics, 91, 697-710. https://doi.org/10.1111/j.1467-8276.2009.01270.x

[13] Bryan, E., Ringler, C., Okoba, B., Roncoli, C., Silvestri, S. and Herrero, M. (2011) Coping with Climate Variability and Adapting to Climate Change in Kenya: Household and Community Strategies and Determinants. Report to the World Bank.

[14] Chege, P.M., Kuria, E.N., Kimiywe, J.O. and Nyambaka, H.N. (2014) Changes in Nutrient Content for $\beta$-Carotene, Iron and Zinc in Solar Dried and Stored Ama- 
ranthus Cruentus Vegetables. International Journal of Agriculture Innovations and Research, 3, 880-882.

[15] Kebede, S.W. and Bokelmann, W. (2017) African Indigenous Vegetables and Their Production Practices: Evidence from the HORTINLEA Survey in Kenya. Agrotechnology, 6, 170. https://doi.org/10.4172/2168-9881.1000170

[16] Abukutsa-Onyango, M.O. (2003) Unexploited Potential of Indigenous African Vegetables in Western Kenya. Maseno Journal of Education Arts and Science, 4, 103-122.

[17] Ngenoh, E., Kebede, S.W., Bett, H.K. and Bokelmann, W. (2016) Role of High-Value Market Participation on Poverty Reduction among African Leafy Vegetable Farmers in Kenya. African Journal of Horticultural Science, 10, 14-20.

[18] Heltberg, R. and Lund, N. (2009) Shocks, Coping, and Outcomes for Pakistan's Poor: Health Risks Predominate. The Journal of Development Studies, 45, 889-910. https://doi.org/10.1080/00220380902802214

[19] Mabuza, M.L., Ortmann, G.F., Wale, E. and Mutenje, M.J. (2016) The Effect of Major Income Sources on Rural Household Food (in) Security: Evidence from Swaziland and Implications for Policy. Ecology of Food and Nutrition, 55, 209-230. https://doi.org/10.1080/03670244.2015.1121482

[20] Deaton, A. (2005) Franco Modigliani and the Life Cycle Theory of Consumption. Research Program in Development Studies and Center for Health and Wellbeing. https://doi.org/10.2139/ssrn.686475

[21] Frankenberg, E., Smith, J.P. and Thomas, D. (2003) Economic Shocks, Wealth, and Welfare. Journal of Human Resources, 38, 280-321. https://doi.org/10.2307/1558746

[22] Deaton, A. (1991) Saving and Liquidity Constraints. Econometrica: Journal of the Econometric Society, 59, 1121-1142. https://doi.org/10.2307/2938366

[23] Kinsey, B., Burger, K. and Gunning, J.W. (1998) Coping with Drought in Zimbabwe: Survey Evidence on Responses of Rural Households to Risk. World Development, 26, 89-110. https://doi.org/10.1016/S0305-750X(97)00124-1

[24] Rosenzweig, M.R. and Wolpin, K.I. (1993) Credit Market Constraints, Consumption Smoothing, and the Accumulation of Durable Production Assets in Low-Income Countries: Investments in Bullocks in India. Journal of Political Economy, 101, 223-244. https://doi.org/10.1086/261874

[25] McPeak, J. (2004) Contrasting Income Shocks with Asset Shocks: Livestock Sales in Northern Kenya. Oxford Economic Papers, 56, 263-284. https://doi.org/10.1093/oep/gpf040

[26] Carter, M.R. and Maluccio, J.A. (2003) Social Capital and Coping with Economic Shocks: An Analysis of Stunting of South African Children. World Development, 31, 1147-1163. https://doi.org/10.1016/S0305-750X(03)00062-7

[27] Skoufias, E. and Quisumbing, A.R. (2005) Consumption Insurance and Vulnerability to Poverty: A Synthesis of the Evidence from Bangladesh, Ethiopia, Mali, Mexico and Russia. The European Journal of Development Research, 17, 24-58. https://doi.org/10.1080/09578810500066498

[28] Lay, J., Mahmoud, T.O. and M’Mukaria, G.M. (2008) Few Opportunities, Much Desperation: The Dichotomy of Non-Agricultural Activities and Inequality in Western Kenya. World Development, 36, 2713-2732. https://doi.org/10.1016/j.worlddev.2007.12.003

[29] Mathenge, M.K. and Tschirley, D.L. (2010) Agricultural Shocks and Off-Farm La- 
bor Market Decisions for Rural Households in Kenya. Centre for the Study of African Economies, Oxford.

http://www.csae.ox.ac.uk/conferences/2010-edia/papers/260-Mathenge.pdf

[30] Kochar, A. (1999) Smoothing Consumption by Smoothing Income: Hours-of-Work Responses to Idiosyncratic Agricultural Shocks in Rural India. Review of Economics and Statistics, 81, 50-61. https://doi.org/10.1162/003465399767923818

[31] Carter, M.R., Little, P.D., Mogues, T. and Negatu, W. (2007) Poverty Traps and Natural Disasters in Ethiopia and Honduras. World Development, 35, 835-856.

https://doi.org/10.1016/j.worlddev.2006.09.010

[32] Eriksen, S.H., Brown, K. and Kelly, P.M. (2005) The Dynamics of Vulnerability: Locating Coping Strategies in Kenya and Tanzania. The Geographical Journal, 171, 287-305. https://doi.org/10.1111/j.1475-4959.2005.00174.x

[33] Mullahy, J. (1986) Specification and Testing of Some Modified Count Data Models. Journal of Econometrics, 33, 341-365. https://doi.org/10.1016/0304-4076(86)90002-3

[34] Deb, P. and Trivedi, P.K. (2002) The Structure of Demand for Health Care: Latent Class versus Two-Part Models. Journal of Health Economics, 21, 601-625. https://doi.org/10.1016/S0167-6296(02)00008-5

[35] Grogger, J.T. and Carson, R.T. (1991) Models for Truncated Counts. Journal of Applied Econometrics, 6, 225-238. https://doi.org/10.1002/jae.3950060302

[36] Shonkwiler, J.S. and Shaw, W.D. (1996) Hurdle Count-Data Models in Recreation Demand Analysis. Journal of Agricultural and Resource Economics, 21, 210-219.

[37] Rahman, S. and Akter, S. (2014) Determinants of Livelihood Choices: An Empirical Analysis from Rural Bangladesh. Journal of South Asian Development, 9, 287-308. https://doi.org/10.1177/0973174114549101

[38] Mutabazi, K.D., Amjath-Babu, T.S. and Sieber, S. (2015) Influence of Livelihood Resources on Adaptive Strategies to Enhance Climatic Resilience of Farm Households in Morogoro, Tanzania: An Indicator-Based Analysis. Regional Environmental Change, 15, 1259-1268. https://doi.org/10.1007/s10113-015-0800-7

[39] Gautam, Y. and Andersen, P. (2016) Rural Livelihood Diversification and Household Well-Being: Insights from Humla, Nepal. Journal of Rural Studies, 44, 239-249. https://doi.org/10.1016/j.jrurstud.2016.02.001

[40] Rakotobe, Z.L., Harvey, C.A., Rao, N.S., Dave, R., Rakotondravelo, J.C., Randrianarisoa, J., Ramanahadray, S., Andriambolantsoa, R., Razafimahatratra, H., Rabarijohn, R.H., Rajaofara, H., Ramesona, H. and MacKinnon, J.L. (2016) Strategies of Smallholder Farmers for Coping with the Impacts of Cyclones: A Case Study from Madagascar. International Journal of Disaster Risk Reduction, 17, 114-122. https://doi.org/10.1016/j.ijdrr.2016.04.013

[41] Bryan, E., Ringler, C., Okoba, B., Roncoli, C., Silvestri, S. and Herrero, M. (2013) Adapting Agriculture to Climate Change in Kenya: Household Strategies and Determinants. Journal of Environmental Management, 114, 26-35. https://doi.org/10.1016/j.jenvman.2012.10.036

[42] Barrett, C.B., Bachke, M.E., Bellemare, M.F., Michelson, H.C., Narayanan, S. and Walker, T.F. (2012) Smallholder Participation in Contract Farming: Comparative Evidence from Five Countries. World Development, 40, 715-730. https://doi.org/10.1016/j.worlddev.2011.09.006

[43] Speranza, C.I., Wiesmann, U. and Rist, S. (2014) An Indicator Framework for As- 
sessing Livelihood Resilience in the Context of Social-Ecological Dynamics. Global Environmental Change, 28, 109-119. https://doi.org/10.1016/j.gloenvcha.2014.06.005

[44] Mugi-Ngenga, E.W., Mucheru-Muna, M.W., Mugwe, J.N., Ngetich, F.K., Mairura, F.S. and Mugendi, D.N. (2016) Household's Socio-Economic Factors Influencing the Level of Adaptation to Climate Variability in the Dry Zones of Eastern Kenya. Journal of Rural Studies, 43, 49-60. https://doi.org/10.1016/j.jrurstud.2015.11.004

[45] Wang, C. and Maclaren, V. (2012) Evaluation of Economic and Social Impacts of the Sloping Land Conversion Program: A Case Study in Dunhua County, China. Forest Policy and Economics, 14, 50-57. https://doi.org/10.1016/j.forpol.2011.06.002

[46] Pretty, J. (2008) Agricultural Sustainability: Concepts, Principles and Evidence. Philosophical Transactions of the Royal Society of London B: Biological Sciences, 363, 447-465. https://doi.org/10.1098/rstb.2007.2163

[47] Burney, J.A. and Naylor, R.L. (2012) Smallholder Irrigation as a Poverty Alleviation Tool in Sub-Saharan Africa. World Development, 40, 110-123.

https://doi.org/10.1016/j.worlddev.2011.05.007

[48] Simtowe, F. and Zeller, M. (2006) The Impact of Access to Credit on the Adoption of Hybrid Maize in Malawi: An Empirical Test of an Agricultural Household Model under Credit Market Failure. MPRA Paper, 45.

[49] McCord, P.F., Cox, M., Schmitt-Harsh, M. and Evans, T. (2015) Crop Diversification as a Smallholder Livelihood Strategy within Semi-Arid Agricultural Systems near Mount Kenya. Land Use Policy, 42, 738-750. https://doi.org/10.1016/j.landusepol.2014.10.012

[50] Narrod, C., Roy, D., Okello, J., Avendaño, B., Rich, K. and Thorat, A. (2009) Public-Private Partnerships and Collective Action in High Value Fruit and Vegetable Supply Chains. Food Policy, 34, 8-15. https://doi.org/10.1016/j.foodpol.2008.10.005

[51] Ma, W. and Abdulai, A. (2016) Does Cooperative Membership Improve Household Welfare? Evidence from Apple Farmers in China. Food Policy, 58, 94-102. https://doi.org/10.1016/j.foodpol.2015.12.002

[52] Abukutsa, M.O.O. (2010) African Indigenous Vegetables in Kenya: Strategic Repositioning in the Horticulture Sector. Second Inaugural Lecture of the Jomo Kenyatta University of Agriculture and Technology. 